\title{
Radiographic Evaluation of the Prevalence of Stafne Bone Defect
}

\author{
Evaluación Radiográfica de Prevalencia de Defecto Óseo de Stafne
}

\begin{abstract}
Israel Leal Cavalcante1; Hanna Isa de Oliveira Bezerra²; Amanda Katarinny Goes Gonzaga²; Larissa Moreira-Souza3; Wilson Gustavo $\mathrm{Cral}^{3}$; Patrícia Teixeira de Oliveira2; Renata

Cordeiro Teixeira Medeiros ${ }^{1}$; Deborah Queiroz Freitas ${ }^{3}$ \& Ana Miryam Costa de Medeiros ${ }^{2}$
\end{abstract}

CAVALCANTE, I. L.; BEZERRA, H. I. O.; GONZAGA, A. K. G.; MOREIRA-SOUZA, L.; CRAL, W. G.; DE OLIVEIRA, P. T.; MEDEIROS, R. C. T.; FREITAS, D. Q. \& DE MEDEIROS, A. M. C. Radiographic evaluation of the prevalence of Stafne bone defect. Int. J. Odontostomat., 14(3):348-353, 2020.

\begin{abstract}
Stafne bone defect (SBD) is a bone cavity in the lingual surface of the mandible normally filled by salivary gland tissue. In conventional radiographs, SBD typically resembles a radiolucent unilocular lesion with welldefined margins, localized under the inferior alveolar canal. The diagnosis of SBD is often incidental due to the asymptomatic nature. The aim of this study was to investigate the prevalence of SBDs in a Brazilian population and to describe the radiographic features of the cases reported. This retrospective study evaluated 17,180 digital panoramic radiographs of patients with an indication of radiography for dental treatment seen at three centers located in the three Brazilian states. In each center, two researchers evaluated the images for establishment of the consensual diagnosis of SBD. In the case of disagreement, a third researcher was consulted to reach a final consensus. To assess the prevalence of SBDs, sex and age of patients were considered, and SBDs were classified according to their form and location. Data were submitted to descriptive analysis. Among the 17.180 patients, only $15(0.08 \%)$ had SDB, including 3 women and 12 men. The age range of the patients with SDB was 30-69 years (mean: 49.2). Fourteen cases were located in the posterior region of the mandibular body and one case in the ascending ramus. Stafne bone defect is a rare developmental anomaly that more commonly affects middle-aged men. The condition has a typical radiographic appearance and panoramic radiography is a valuable tool for its diagnosis.
\end{abstract}

KEY WORDS: epidemiology, development, bone, radiography, panoramic, diagnosis, imaging, diagnostic.

\section{INTRODUCTION}

Stafne bone defects (SBDs) were described for the first time by Stafne in 1942, who reported 35 asymptomatic unilateral radiolucent cavities in the mandibular posterior region (Stafne, 1942). These bone cavities generally measure 1 to $3 \mathrm{~cm}$ in diameter and are located on the lingual surface of the posterior mandible between the mandibular angle and third molar, below the mandibular canal and above the mandibular base. The prevalence of SBDs at this posterior site ranges from $0.10 \%$ to $0.48 \%$. The posterior variant is mainly diagnosed in men between
50 and 70 years of age (Asaaf et al., 2014). The anterior variant is often located in the region between the incisors and premolars, and its prevalence is generally seven times lower than that of the posterior variant (Asaaf et al., 2014; Phillips \& Yates, 2004).

Many different terms have been used to describe this condition, including ectopic salivary glands, static bone cyst, lingual mandibular bone defect, Stafne bone cavity, idiopathic bone cavity, or lingual mandibular bone depression (Philipsen et al., 2002;

\footnotetext{
${ }^{1}$ Department of Dentistry, University of Fortaleza (UNIFOR), Fortaleza, Ceará, Brazil.

${ }^{2}$ Department of Dentistry, Postgraduate Program in Oral Pathology, Federal University of Rio Grande do Norte (UFRN), Natal, Rio Grande do Norte, Brazil.

${ }^{3}$ Department of Oral Diagnosis, Division of Oral Radiology, Piracicaba Dental School, University of Campinas (UNICAMP), Piracicaba, São Paulo, Brazil.
} 
CAVALCANTE, I. L.; BEZERRA, H. I. O.; GONZAGA, A. K. G.; MOREIRA-SOUZA, L.; CRAL, W. G.; DE OLIVEIRA, P. T.; MEDEIROS, R. C. T.; FREITAS, D. Q. \& DE MEDEIROS, A. M. C. Radiographic evaluation of the prevalence of Stafne bone defect. Int. J. Odontostomat., 14(3):348-353, 2020.

Sisman et al., 2012; Avsever et al., 2015). As most of the terms clarify, SBD is not a pathology but seems to be related to the pressure exerted by the submandibular gland, or by the sublingual gland in the case of the anterior variant, which causes bone resorption in the region (Philipsen et al.; Shimizu et al., 2006; Sisman et al.; Avsever et al.).

Since SBDs are usually asymptomatic, they are discovered accidentally in imaging tests. In view of the similarity of SBD with some lesions, it is important for the professional to be able to identify the condition. The differential diagnosis should include bone cysts and cyst-like lesions such as solitary bone cysts, aneurysmal bone cysts and traumatic-hemorrhagic bone cysts (Asaaf et al., 2014).

The objective of this study was to describe the clinical and radiographic characteristics of SBDs diagnosed at three referral centers for Oral and Maxillofacial Radiology in Brazil, to estimate their frequency in the Brazilian population, and to compare the results with literature data.

\section{MATERIAL AND METHOD}

This was an observational retrospective study conducted three referral centers for Oral and Maxillofacial Radiology in Brazil, in the states of São Paulo, Rio Grande do Norte and Ceará. The study was approved by the local Institutional Ethics Committee (Approval No. Protocol 1,858,957 - CAAE: 59959616.8.0000.5537).

The sample consisted of 17,180 digital panoramic radiographs from the image databases of the Oral and Maxillofacial Radiology clinics of the School of Dentistry, University of Fortaleza (Fortaleza, Ceará, Brazil), obtained between 2010 and 2016; of the Department of Dentistry of Federal University of Rio Grande do Norte (Natal, Rio Grande do Norte, Brazil), obtained between 2013 and 2016; and of the Piracicaba School of Dentistry of Campinas State University (Piracicaba, São Paulo, Brazil), obtained between 2015 and 2017. Were included panoramic radiographs which exhibited no positioning errors or jaw bone lesions.

The following devices were used for the imaging tests: Orthopantomograph OP 100D
(Instrumentarium Corp., Imaging Division, Tuusula, Finland), Pax-400 Vatech (Hwaseong-si, Gyeonggido, Korea), and Kodak 8000c (Carestream Health, São Paulo, Brazil). The Kodak Dental Image Software Viewer (version 6.12.10.0) was used to evaluate the images on a standard personal computer equipped with a 20 " calibrated monitor (LCD HP Compaq LE1711 Monitor, Palo Alto, CA, USA).

Six calibrated oral radiologists with at least 4 years experience in the interpretation of imaging tests examined the images for establishment of the consensual diagnosis of SBD. Two in each center evaluated the panoramic radiograph in a silent room without artificial or natural lighting. Zoom in and/or zoom out as well as brightness and contrast tool were allowed to enhance the images. In the case of disagreement between the evaluators, a third researcher oral radiology specialist was consulted to reach a final consensus.

The criteria proposed by Schneider et al. (2014) were adopted for the diagnosis of SBD: round or oval mandibular radiolucency of homogenous appearance located below the mandibular canal, with marked cortical demarcation and clear distinction of neighboring anatomical structures.

The age, sex, laterality, location, and shape of the SBD cases were recorded. The results were entered into Excel spreadsheets and analyzed descriptively.

\section{RESULTS}

A total of 17,180 radiographs met the inclusion criteria and were examined. Fifteen $(0.08 \%)$ of these cases were diagnosed as SBD, 12 in men and 3 in women (Table I).

The age of the patients diagnosed as SBD ranged from 30 to 69 years, with a mean of 49.2 years. Regarding location, 5 cases involved the left side and 10 cases, the right side. The anterior and bilateral presentations were not observed. Table I shows the distribution of the cases according to patient age and sex, as well as the location and shape of the SBDs found. Figure 1 shows the images of the 15 cases diagnosed as SBD. 

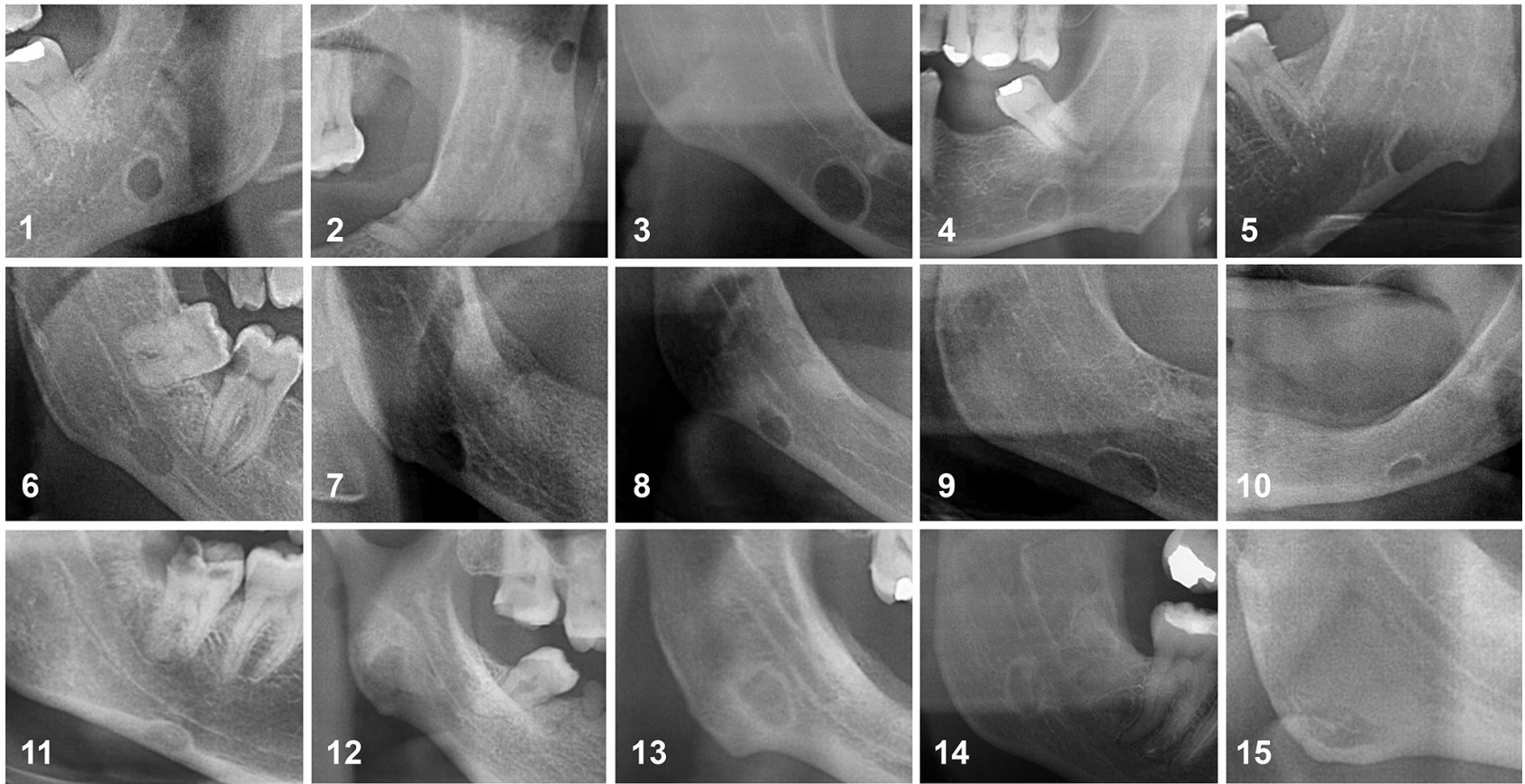

Fig. 1. Stafne bone defects detected on digital panoramic radiographs. Case 2 was located in the ascending ramus and the remaining cases in the posterior region of the mandibular body.

Table I. Characteristics of the cases diagnosed in the present study with Stafne bone defects by panoramic radiography.

\begin{tabular}{ccclc}
\hline Case & Age (years) & Sex & Location of SBD & Shape \\
\hline 1 & 53 & M & Left body & Round \\
2 & 61 & M & Left ramus & Oval \\
3 & 50 & M & Right body & Round \\
4 & 64 & M & Left body & Round \\
5 & 39 & M & Left body & Oval \\
6 & 39 & M & Right body & Oval \\
7 & 54 & M & Right body & Oval \\
8 & 53 & M & Right body & Oval \\
9 & 69 & M & Right body & Oval \\
10 & 65 & M & Left body & Oval \\
11 & 30 & M & Right body & Oval \\
12 & 43 & F & Right angle & Oval \\
13 & 35 & M & Right angle & Oval \\
14 & 37 & F & Right angle & Oval \\
15 & 47 & F & Right angle & Oval \\
\hline
\end{tabular}

SBD: Stafne bone defect; M: Male; F: Female.

\section{DISCUSSION}

In general, SBD is an incidental finding during the interpretation of imaging tests, especially panoramic radiographs and cone beam computed tomography scans, where it appears as an oval or round, uni- or bilateral, generally corticated, radiolucent image located near the mandibular angle, below the inferior alveolar canal. It mainly affects the posterior region of the mandible and is rarely found in the anterior region (Avsever et al.). The description of the bone lesion as latent, stable or static is due to the fact that it persists unchanged over long periods (Asaaf et al., 2014).

Several theories try to explain the etiopathology of SBD (Sisman et al.). One theory suggests a congenital or embryonic origin of the condition. According to this theory, SBD is the result of mandibular hypoplasia during growth and development (Stafne). The main objection to this theory is that these defects are more frequently diagnosed in adults than in children, suggesting that they develop after ossification of the mandible. The youngest patient with SBD reported in the literature was 11 years old (Hansson, 1980). In this respect, the findings of the present study support the objection to this theory since the youngest patient diagnosed with SBD was 30 years.

Another theory suggests that SBD is caused by the constant pressure from the salivary gland tissue (Sisman et al.). According to this theory, the submandibular gland is related to posterior defects, while the sublingual gland is related to anterior defects (Philipsen et al.; Avsever et al.). Some authors defend 
acquired vascular lesions to be a possible cause of bone depression (Minowa et al., 2003, 2006). Further studies are needed to clarify the true etiology of this condition.

According to a literature review, SBDs are commonly diagnosed in men between 50 and 70 years of age (Sisman et al.; Avsever et al.). This trend of a higher prevalence in male patients was observed in the present study (male-to-female ratio of $4: 1$ ), in agreement with previous studies that found ratios of $6: 1,1.5: 1,6: 1$, and 2:1 (Philipsen et al.; Quesada-Gómez et al., 2006; Sisman et al.; Avsever et al.).

Stafne bone defects are generally diagnosed in patients older than 20 years, most of them in the fifth and sixth decades of life (Sisman et al.). Similarly, the 15 cases of SBD included in the present study were patients aged 30 to 69 years (mean 49.2 years).

The low prevalence of SBDs (ranging from 0.08 to $0.40 \%$ in previous studies (Lilly et al., 1965 ; Karmiol \& Walsh, 1968; Johnson, 1970; Oikarinen \& Julku, 1974; Uemura et al., 1976; Correll et al., 1980; Chen \& Ohba, 1981; Sisman et al.; Asaaf et al., 2014; Avsever et al.) (Table II) was confirmed in the present study, in which the prevalence was $0.08 \%$. The same rate was reported in other studies investigating different populations (Sisman et al.; Asaaf et al., 2014; Avsever et al.). The anterior variant is even lower prevalence, $0.003 \%$ according to Sisman et al. This fact may explain why this variant was not found in the present study.

In most cases, SBDs are unilateral but bilateral defects are observed occasionally. No bilateral defects were found in the present study. To our knowledge, there are only 9 cases of bilateral anterior SBDs reported in the literature (Queiroz et al., 2004; Kim et al., 2014;
Sekerci \& Sisman, 2014). Generally, SBDs are located in the posterior region of the mandibular body or in the mandibular angle, below the mandibular canal. These defects are rare in the ramus, coronoid process, or anterior mandible. In the present study, 14 cases were located in the posterior region of the mandibular body and only one case in the left mandibular ramus.

Hisatomi et al. (2019) evaluated the distribution according to age, sex, shape and location of 91 cases of SBD, and obtained similar results with the present study: higher prevalence in males, with average age of 60.8 years; and the most prevalent features were unilateral defect with radiolucent degree, thick sclerotic bone margin in the entire contour of the defect, oval shape, and unilocularity; the posterior variant was the most frequent.

Since SBDs are asymptomatic, most cases are discovered accidentally during imaging examinations. However, in some case reports the patients reported pain at the site of the SBD (Bornstein et al., 2009; Turkoglu \& Orhan, 2010). In this retrospective analysis of previous anamnesis, none of the patients had pain, swelling or infection and all cases were discovered by evaluation of panoramic radiographs.

The correct identification of SBD is important because the posterior mandible is prone to develop pathological lesions. Thus, the differential diagnosis of SBD should include pathologies such as odontogenic cystic lesions, vascular malformations, unicystic ameloblastoma, giant cell granuloma, odontogenic keratocyst, aneurysmal bone cyst, benign salivary gland tumors, and neurogenic tumors (Sisman et al.; Avsever et al.). One important feature to distinguish between SBD and other conditions is the location of the former below the mandibular canal.

Table II. Prevalence of Stafne bone defects in the literature.

\begin{tabular}{lcccc}
\hline Author(s) & $\begin{array}{c}\text { Year of } \\
\text { publication }\end{array}$ & $\begin{array}{c}\text { Number of cases } \\
\text { analyzed }\end{array}$ & $\begin{array}{c}\text { Number of } \\
\text { SBDs }\end{array}$ & $\begin{array}{c}\text { Prevalence } \\
(\%)\end{array}$ \\
\hline Lilly et al. & 1965 & 1,283 & 2 & 0.16 \\
Karmi ol \& Walsh & 1968 & 4,693 & 18 & 0.38 \\
Johnson & 1970 & 2,486 & 10 & 0.40 \\
Oikarinen \& Julku & 1974 & 10,000 & 10 & 0.10 \\
Uemura et al. & 1976 & 3,000 & 10 & 0.33 \\
Correl et al. & 1980 & 2,693 & 13 & 0.48 \\
Chen \& Ohba & 1981 & 23,000 & 24 & 0.10 \\
Siman et al. & 2012 & 34,221 & 29 & 0.08 \\
Assaf et al. & 2014 & 14,005 & 11 & 0.08 \\
Avsaver et al. & 2015 & 14,058 & 13 & 0.09 \\
Current study & - & 17,180 & 15 & 0.08 \\
\hline
\end{tabular}

SBD: Stafne bone defect. 
In most cases, the diagnosis of SBD is easy, because of its specific appearance on radiographs. The defects are usually detected on conventional or digital panoramic radiographs. These imaging methods generally provide sufficient information for the diagnosis of SBDs and were therefore used in the present study. Panoramic radiography is widely used in dentistry because of its broad availability and the low radiation dose. More advanced imaging techniques such as computed tomography, magnetic resonance imaging and even sialography should be restricted to atypical lesions, when the final diagnosis cannot be made by panoramic radiography (Avsever et al.). This restriction is due to the higher radiation dose, higher cost and/or greater invasiveness of the cited methods.

Treatment of the posterior or anterior variants of SDB is not necessary since these mandibular bone depressions were found to be a change in the anatomical condition and are not pathological. A conservative approach consisting of clinical and imaging follow-up is generally recommended. Surgical procedures or biopsies should only be performed in atypical cases or if notable changes are observed during radiographic follow-up (Sisman et al.; Avsever et al.).

\section{ACKNOWLEDGMENTS}

This study was financed in part by the Coordenação de Aperfeiçoamento de Pessoal de Nível Superior - Brasil (CAPES) and Conselho Nacional de Desenvolvimento Científico e Tecnológico - Brasil (CNPq) - Finance Code 001.

CAVALCANTE, I. L.; BEZERRA, H. I. O.; GONZAGA, A. K. G.; MOREIRA-SOUZA, L.; CRAL, W. G.; DE OLIVEIRA, P. T.; MEDEIROS, R. C. T.; FREITAS, D. Q. \& DE MEDEIROS,

A. M. C. Evaluación radiográfica de prevalencia de defecto óseo de Stafne. Int. J. Odontostomat., 14(3):348-353, 2020.

RESUMEN: El defecto óseo de Stafne (DOS) es una cavidad ósea en la superficie lingual de la mandíbula, normalmente llena de tejido glandular salival. En las radiografías convencionales, el DOS generalmente se asemeja a una lesión unilocular radiotransparente con bordes bien definidos, ubicada debajo del canal alveolar inferior. El diagnóstico de DOS a menudo es accidental debido a su naturaleza asintomática. El objetivo de este estudio fue investigar la prevalencia de DOS en una población brasileña y describir las características radiográficas de los casos reportados.
Este estudio retrospectivo evaluó 17.180 radiografías panorámicas digitales de pacientes con indicación radiográfica para tratamiento dental atendidos en tres centros ubicados en tres estados brasileños. En cada centro, dos investigadores evaluaron las imágenes para establecer un diagnóstico consensuado de DOS. En caso de desacuerdo, se consultó a un tercer investigador para llegar a un consenso final. Para evaluar la prevalencia de DOS, se consideraron el sexo y la edad de los pacientes, y se clasificaron según su forma y ubicación. Los datos fueron sometidos a análisis descriptivo. Entre los 17.180 pacientes, solo $15(0,08 \%)$ tenían DOS, incluidos 3 mujeres y 12 hombres. El rango de edad de los pacientes con DOS fue de 30 a 69 años (media: $49,2)$. Catorce casos se ubicaron en la región posterior del cuerpo mandibular y un caso en la rama ascendente. Los defectos óseos de Stafne son una anomalía rara del desarrollo que afecta más comúnmente a los hombres de mediana edad. La condición tiene una apariencia radiográfica típica y la radiografía panorámica es una herramienta valiosa para su diagnóstico.

PALABRAS CLAVE: epidemiologia, desarrollo ósseo, radiografía panorâmica, diagnóstico, diagnóstico por imagen.

\section{REFERENCES}

Assaf, A. T.; Solaty, M.; Zrnc, T. A.; Fuhrmann, A. W.; Scheuer, H.; Heiland, M. \& Friedrich, R. E. Prevalence of Stafne's bone cavity-retrospective analysis of 14,005 panoramic views. In Vivo, 28(6):1159-64, 2014.

Avsever, H.; Kurt, H.; Suer, T. B. \& Ozgedik, H. S. Stafne bone cavity: A retrospective panoramic evaluation on prevalence in Turkish subpopulation. J. Exp. Integr. Med., 5(2):89-92, 2015

Bornstein, M. M.; Wiest, R.; Balsiger, R. \& Reichart, P. A. Anterior Stafne's bone cavity mimicking a periapical lesion of endodontic origin: report of two cases. J. Endod., 35(11):1598-602, 2009.

Chen, C. Y. \& Ohba, T. An analysis of radiological findings of Stafne's idiopathic bone cavity. Dentomaxillofac. Radiol., 10(1):18-23, 1981.

Correll, R. W.; Jensen, J. L. \& Rhyne, R. R. Lingual cortical mandibular defects: a radiographic incidence study. Oral Surg. Oral Med. Oral Pathol., 50(3):287-91, 1980.

Hansson, L. G. Development of a lingual mandibular bone cavity in an 11-year-old boy. Oral Surg. Oral Med. Oral Pathol., 49(4):3768, 1980.

Hisatomi, M.; Munhoz, L.; Asaumi, J. \& Arita, E. S. Stafne bone defects radiographic features in panoramic radiographs: Assessment of 91 cases. Med. Oral Patol. Oral Cir. Bucal, 24(1):e12-9, 2019.

Johnson, C. C. Analysis of panoramic survey. J. Am. Dent. Assoc., 81(1):151-4, 1970.

Karmiol, M. \& Walsh, R. F. Incidence of static bone defect of the mandible. Oral Surg. Oral Med. Oral Pathol., 26(2):225-8, 1968.

Kim, H.; Seok, J. Y.; Lee, S.; An, J.; Kim, N. R.; Chung, D. H.; Cho, H. Y. \& Ha, S. Y. Bilateral stafne bone cavity in the anterior mandible with heterotopic salivary gland tissue: a case report. Korean J. Pathol.., 48(3):248-9, 2014.

Lilly, G. E.; Steiner, M.; Irby, W. B. \& Tiecke, R. W. Oral health evaluation: analysis of radiographic findings. J. Am. Dent. Assoc., 71:635-9, 1965. 
CAVALCANTE, I. L.; BEZERRA, H. I. O.; GONZAGA, A. K. G.; MOREIRA-SOUZA, L.; CRAL, W. G.; DE OLIVEIRA, P. T.; MEDEIROS, R. C. T.; FREITAS, D. Q. \& DE MEDEIROS, A. M. C. Radiographic evaluation of the prevalence of Stafne bone defect. Int. J. Odontostomat., 14(3):348-353, 2020.

Minowa, K.; Inoue, N.; Izumiyama, Y.; Ashikaga, Y.; Chu, B.; MaraviIla, K. R.; Totsuka, Y. \& Nakamura, M. Static bone cavity of the mandible: Computed tomography findings with histopathologic correlation. Acta Radiol., 47(7):705-9, 2006.

Minowa, K.; Inoue, N.; Sawamura, T.; Matsuda, A.; Totsuka, Y. \& Nakamura, M. Evaluation of static bone cavities with CT and MRI. Dentomaxillofac. Radiol., 32(1):2-7, 2003.

Oikarinen, V. J. \& Julku, M. An orthopantomographic study of developmental mandibular bone defects (Stafne's idiopathic bone cavities). Int. J. Oral Surg., 3(2):71-6, 1974.

Philipsen, H. P.; Takata, T.; Reichart, P. A.; Sato, S. \& Suei, Y. Lingual and buccal mandibular bone depressions: a review based on 583 cases from a world-wide literature survey, including 69 new cases from Japan. Dentomaxillofac. Radiol., 31(5):281-90, 2002.

Phillips, A. \& Yates, C. Case report: anterior lingual mandibular cortical bone concavity. Dent. Update, 31(3):175-6, 2004.

Queiroz, L. M.; Rocha, R. S.; de Medeiros, K. B.; da Silveira, E. J. \& Lins, R. D. Anterior bilateral presentation of Stafne defect: an unusual case report. J. Oral Maxillofac. Surg., 62(5):613-5, 2004.

Quesada-Gómez, C.; Valmaseda-Castellón, E.; Berini-Aytés, L. \& Gay-Escoda, C. Stafne bone cavity: a retrospective study of 11 cases. Med. Oral Patol. Oral Cir. Bucal, 11(3):E277-80, 2006.

Schneider, T.; Filo, K.; Locher, M. C.; Gander, T.; Metzler, P.; Grätz, K. W.; Kruse, A. L. \& Lübbers, H. T. Stafne bone cavities: systematic algorithm for diagnosis derived from retrospective data over a 5-year period. Br. J. Oral Maxillofac. Surg., 52(4):369-74, 2014.

Sekerci, A. E. \& Sisman, Y. Bilateral anterior Stafne bone defect mimicking radicular cyst: report of a rare case with a review of the literature. Oral Radiol., 30:115-22, 2014

Shimizu, M.; Osa, N.; Okamura, K. \& Yoshiura, K. CT analysis of the Stafne's bone defects of the mandible. Dentomaxillofac. Radiol., 35(2):95-102, 2006.

Sisman, Y.; Miloglu, O.; Sekerci, A. E.; Yilmaz, A. B.; Demirtas, O. \& Tokmak, T. T. Radiographic evaluation on prevalence of Stafne bone defect: a study from two centres in Turkey. Dentomaxillofac. Radiol., 41(2):152-8, 2012.

Stafne, E. C. Bone cavities situated near the angle of the mandible. J. Am. Dent. Assoc., 29(17):1969-72, 1942.

Turkoglu, K. \& Orhan, K. Stafne bone cavity in the anterior mandible. J. Craniofac. Surg., 21(6):1769-75, 2010.

Uemura, S.; Fujishita, M. \& Fuchihata, H. Radiographic interpretation of so-called developmental defect of mandible. Oral Surg. Oral Med. Oral Pathol., 41(1):120-8, 1976.
Corresponding author:

Israel Leal Cavalcante

Department of Dentistry

University of Fortaleza

Av. Washington Soares 1321

Edson Queiroz

CEP 60811-905

Fortaleza, CE

BRAZIL

E-mail: israelleal@unifor.br

Received: 28-01-2020

Accepted: 02-03-2020 